\title{
Human Resource Management Practices and Workplace Deviant Behaviour of Manufacturing Firms in Rivers State, Nigeria
}

\author{
Joseph Akhigbe Omoankhanlen and Adamu Momodu Mutairu
}

\section{ABSTRACT}

\begin{abstract}
The nexus between human resource management practices and workplace deviant behaviour in manufacturing companies in Rivers State, Nigeria, was investigated in this study. The sample was conducted in a crosssectional manner. This study looked at 470 staff from six manufacturing companies. In order to minimize bias in sample case collection, this analysis utilized a simple random sampling method. The primary data was collected using a questionnaire that was provided to each respondent. The spearman rank order correlation coefficient was used to analyze the results. According to the findings, human resources management practices (compensation and employee relations) had a negative significant relationship with both interpersonal and organizational deviant behaviour, with the exception of compensation and interpersonal deviance, which had no significant relationship. It was determined that an efficient human resource management practice in terms of compensation and employee relations is critical in reducing the occurrence of deviant behaviour by manufacturing employees. As a result, the study proposed that manufacturing company management improve workforce relations by caring for workers' well-being and maintaining industrial cohesion, which would further minimize individual and corporate deviant conduct.
\end{abstract}

Keywords: Compensation, Deviant Behaviour, Employee Relations, Interpersonal Deviant, Organizational Deviant.
Submitted : March 16, 2021

Published : April 27, 2021

ISSN: 2507-1076

DOI: $10.24018 /$ ejbmr.2021.6.2.814

Joseph Akhigbe Omoankhanlen *

Department of Management, University of Port Harcourt, Port Harcourt, Nigeria.

(e-mail: joseph.omoankhanlen ${ }^{\circledR}$ uniport.edu.ng) Adamu Momodu Mutairu

Department of Management, University of Port Harcourt, Port Harcourt, Nigeria.

(e-mail: mutaria@yahoo.com

\section{INTRODUCTION}

Due to the high level of competition among companies in the global market, as well as the high level of dynamism in the business environment, several organisations are focusing their efforts on improving positive work behaviour among employees. Organizations are always looking at opportunities to improve healthy work attitudes and eradicate disruptive organizational behaviour in this age of never-ending corporate warfare. Because of its detrimental effect on a company's long-term viability and competition, eliminating workplace deviant behaviour is becoming increasingly important. Organizations can be well-equipped for advanced technologies, but this does not guarantee the firm's survival. Without the intervention of the human factor, any of a company's available capital have little to no effect. As a result, it is critical to ensure that certain workers behave in a way that benefits the business. According to [1], it is critical for businesses to eradicate deviant behaviour in the workplace because businesses depend on their workers to increase their productivity. Employee deviant behaviour has been referred to by a variety of terms, including counterproductive behaviour [2]. Deviant behaviour may also be described as any conduct that breaches an organization's rules, guidelines, or norms [3].

According to studies, occupational deviant behaviour is linked to a lack of compliance with human capital management policies in the workplace [4]. Deviant behaviour can be seen in any organization, no matter how small. However, the extent to which these behaviours are shown by workers has a significant impact on the company's financial success and resilience. Interpersonal deviance and organizational deviance are two broad measures of deviant behaviour defined by [5]. Employees are reasonable individuals whose actions and behaviours are conditioned by a variety of factors. As a result, based on the human resources management procedures in place, the degree to which employees engage in deviant behaviour can either increase or decrease. Staff who have seen deviant behaviour are more likely to retreat or show low morale, according to [6], which may have a detrimental effect on the business. Employees can consider a disparity between what they contribute to the enterprise and what they obtain in exchange. Such employees can engage in deviant behaviour such as absenteeism, withdrawing efforts, bribery, destruction, fraud, and sabotage in order to bridge the gap. As a result, human resource management practices may be crucial in resolving disruptive workplace behaviour. The processes, procedures, and policies that affect employee efficiency, behaviour, and attitude are known as human resources management practices [7]. According to [8], occupational deviance may be constructive or destructive. They said that it is beneficial when it benefits employees and 
the company, but it is detrimental when it is used to hurt employees or the organization.

Human resource management practices, on the other hand, was described by [9] as the collection of human resource requirements, evaluation, recruiting, staff preparation, rewarding, assessment, labor relations, safety and health, and justice issues. Human resource policy and preparation, recruiting, and success assessment are some of the various aspects of human resource management strategies defined by [10]. Human resource selection, recruiting, preparation, reward, evaluation, protection and health, and labor relations are all aspects of human resource practices, according to [9]. In order to gain a comparative edge over competitors, HRMP must be implemented effectively and wisely in the workplace. HRMP, according to [11] increases employee awareness, synergy, inspiration, and loyalty to the business. Human resource management activities, according to [12], are critical in ensuring that companies meet their predetermined objectives.

Many researchers have sought to see how different constructs may better address the problem of occupational deviant behaviour, based on the necessity of preventing deviant behaviour. Reference [13] investigated the relationship between leadership and workplace deviant conduct. Reference [14] investigated the relationship between corporate justice and deviant occupational conduct. Reference [15] have looked at the psychology of deviant behaviour in the workplace and illegal behaviour. Reference [16] investigated how corporate faith and employee fulfillment can be used to mitigate deviant conduct. Other researchers have looked into how job satisfaction affects deviant behaviour [17]; other study in advanced countries has found a connection between human resource management strategies and workplace deviant behaviour [17], [18]. Despite the many studies that have been conducted about how to eliminate the problem of deviant workplace behaviour, the majority of the research on the relationship between human resource management practices and workplace deviant behaviour has been conducted in developing countries. However, there is a scarcity of analytical study in the Nigerian workplace that examines the relationship between human resource management practices and workplace deviant conduct. This study is based on the observation of a gap.

\section{Statement OF THE PROBLEM}

The manufacturing firm in Nigeria has over the years experienced poor growth and most firms has liquidated due to inability to withstand the harsh economic environment. The manufacturing firms which ought to have been the "life blood" of the Nigerian economy has contributed little to the Gross Domestic Product (GDP) of the country in recent years. In most advance countries, the manufacturing firms are booming and has helped reduce the rate of unemployment and hunger in the country. Reference [21] pointed out that the stable American and European states have industries that has created an enabling environment for its citizens to be employed and usefully engaged, thereby eliminating want, social miscreant, unemployment, poverty and hunger. But such cannot be said of Nigeria industries vis-à-vis manufacturing firms whose activities has been crippled due to harsh economic environment and various actions by individual employee within the organization. Worthy of note is the deviant behaviour in the workplace which is capable of negatively affecting the wellbeing of the organization. Deviant behaviour in the workplace has been a critical problem over the years which started around the industrial revolution period [22]. Interpersonal deviant in the workplace was triggered due to excessive control and order, the abusive harassment and supervision of employees endured in the workplace in the eighteenth century. During this era, employees destroyed machinery which were made to replace certain job functions [23]. The deviant behaviour has increased over time and has negatively affected the fortune of the firm. The problem of deviant behaviour manifest in various ways which over the period has reduced the financial performance of the organization.

Workplace negative deviant behaviours have cost firm a huge financial loses. Economically, the cost of employee fraud, theft, and other kind of deviant behaviours courses a huge loss of value to the firm. Interpersonal deviant behaviours like verbal abuse, stealing from co-workers, sexual harassment, showing favouritism and gossiping coworkers can reduce work morale in the organization and also impede on the extent of cohesion among the employees. Organizational deviant like sabotaging equipment, lateness, stealing from the organization and wasting of organizational resources reduces the performance of firms and their competitiveness in the industry. Despite the numerous work that has been done to examine how the issue of deviant behaviour can be resolved, the problem still persist mostly in the manufacturing firm in Nigeria. It is on this note that this study examined the relationship between human resources management practices and workplace deviant behaviour of manufacturing firms in Rivers state, Nigeria.

\section{RESEARCH OBJECTIVES}

The specific research objectives are to examine the relationship between;

i. Compensation and interpersonal deviant of manufacturing firms in Rivers state, Nigeria.

ii. Compensation and organizational deviant of manufacturing firms in Rivers state, Nigeria.

iii. Employee relations and interpersonal deviant of manufacturing firms in Rivers state, Nigeria.

iv. Employee's relations and organizational deviant of manufacturing firms in Rivers state, Nigeria.

\section{RESEARCH QUESTIONS}

The following research questions serve as guide in this research work:

I. What is the relationship between compensation and interpersonal deviant of manufacturing firms in Rivers State, Nigeria?

II. What is the relationship between compensation and organizational deviant of manufacturing firms in Rivers state, Nigeria? 
III. What is the relationship between employee relations and interpersonal deviant of manufacturing firms in Rivers state, Nigeria?

IV. What is the relationship between employee relations and organizational deviant of manufacturing firms in Rivers state, Nigeria?

\section{RESEARCH HYPOTHESES}

Ho1: There is no significant relationship between compensation and interpersonal deviant of manufacturing firms in Rivers state, Nigeria.

Ho2: There is no significant relationship between compensation and organizational deviant of manufacturing firms in Rivers state, Nigeria.

Ho3: There is no significant relationship between employee relations and interpersonal deviant of manufacturing firms in Rivers state, Nigeria.

Ho4: There is no significant relationship between employees' relations and organizational deviant of manufacturing firms in Rivers state, Nigeria.

\section{REVIEW OF RELATED LITERATURE}

This study's premise is based on the social control theory, which states that people's relationship commitments, interests, norms, and beliefs motivate them to follow the rules. Individuals can willingly curb their tendency to perform deviant actions if moral norms are internalized and they are connected to and invested in their larger group. Reference [24] introduced this hypothesis in 1901, defining social regulation as the idea that the smoother the social machinery runs, the more regular the breaking off or setting aside of human acts, and the more perfect the social order becomes. As a result, this philosophy emphasizes people's participation in events in their immediate and larger communities, as well as being a stakeholder, in order to minimize deviant behaviour, especially negative deviant behaviour. In the same way, such a management theory would greatly mitigate workplace deviant conduct.

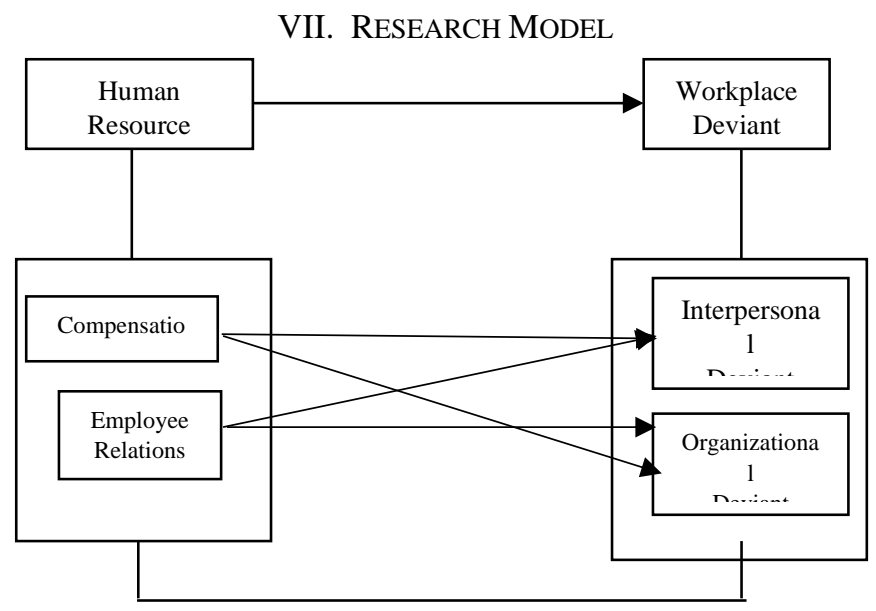

Source: [2], [9].

\section{CONCEPT OF HumAn RESOURCE MANAGEMENT PRACTICES (HRMP)}

Human resource practices are constantly being recognized as having an effect on organizational performance and competitive advantage, and companies that experience these practices are those that use effective people management methods [25]. Human Resources (HR) is a concept used to identify the people who make up an organization's employees. Human resource management practices such as recruiting, hiring, preparation, and compensation are carried out with the company's priorities and expectations in mind, which are identified by strategies. Organizations have been able to produce excellent results by aligning HR operations with their strategic priorities [26]. Human resource management strategies are a method of handling employees in an organization that involves a series of interconnected tasks that occur until an individual is employed and last until the employee's job is terminated. Human resource management (HRM) is a motivation that influences employee behaviour in the workplace and is linked to change management [27]. Employees may be encouraged to change their attitudes by using good human resource strategies. A variety of causes remain outside the influence of the company, although some are within its control. Human resources are remembered as the most significant and useful assets that plays an important role in the effectiveness and competitiveness of businesses among the controllable variables.

\section{A. Compensation as a Dimension of Human Resource Management Practices (HRMP)}

Compensation may be described as a tool for appreciating an employee's contributions to the employer/organization. According to [28], pay encompasses both aspects of remuneration. Compensation, according to [29], applies to both the salaries received specifically for time employed as well as the more indirect incentives that workers earn as part of their career or working arrangement with an organisation. Compensation is mostly in the form of monetary or nonmonetary compensation. Reference [30] stated that wage and salary administration priorities would foster employeremployee relationships through employee cooperation, that is, corporate deviance elimination through pay, and encourage workers to achieve optimal job efficiency while addressing the goals and policies of wage and salary administration. Reference [29] argued that employees should be compensated fairly and adequately, rather than being paid scraps, in order to improve their attitude toward employment and increase employee satisfaction.

\section{B. Employee Relations as a Dimension of Human Resource Management Practices (HRMP)}

Employee relations refers to how people interact with their co-workers and with the company as a whole. Relationships are subjective in essence and they can only be sensed and not observed. It is, nevertheless, critical in any company. The sector is associated with informing workers of the organization's priorities such that they have a greater understanding of the management's goals and policies [31]. Employee relations is associated with the overall management of the work arrangement as well as the creation 
of a favorable psychological deal. They specifically address work terms and conditions, employment-related topics, giving workers a forum, and engaging with employees. Employees are negotiated with either personally or by collective bargaining arrangements in the case of recognised labor unions [32]. Employee relations investigates the different facets of how workers interact at work. Employee relations, then, refers to how workers communicate with one another as well as with their bosses. This type of conversation may be structured or casual. Which includes all aspects of administration, such as labor affairs, staff engagement and interaction, employee contact, and industrial relations [33]. Employee interactions are structured where they are limited to agreed-upon and registered terms and conditions between staff and employers, but they are casual when they extend beyond traditional practices within the organisation, such as managers' interest in personal matters that might be bothering their subordinates.

\section{IX.CONCEPT OF DEVIANT BEHAVIOUR}

Deviant behaviour, in most situations, refers to actions that go beyond a society's or organization's defined values. Deviant behaviour may be constructive if it is used to enhance established values such as innovation, or it can be harmful if it is used to undermine and/or hinder established principles and/or processes such as "pilfering" or the deliberate degradation of fellow employees and/or company assets. Deviant occupational conduct, according to [19], as quoted in [2], is voluntary behaviour that violates major organizational norms and hence endangers the organization's and its members' wellbeing. Stealing or destroying workplace goods, arriving late at work without formal approval, harassing others at work, and so on are all instances of deviant workplace conduct, according to [19]. Interpersonal and organizational deviant behaviour are the two indicators of workplace deviant behaviour defined by [2].

Unethical pro-organizational behaviour (UPB) is one kind of organizational deviant behaviour. According to [34], immoral pro-organizational behaviour is often not justified because it violates the workplace code of ethics. However, according to [35], UPB are often carried out on purpose by employees of the association in order to support the organization at the expense of the clients.

\section{A. Interpersonal Deviance as a Measure of Deviant Behaviour}

Interpersonal deviance is described as inappropriate behaviour aimed at co-workers (e.g., verbally lashing at coworkers, bullying and humiliating co-workers). According to [5], interpersonal deviance is voluntary behaviour that breaches major organizational rules, endangering the wellbeing of the organisation, the participants, or both. Making fun of coworkers, behaving rudely against others, accusing coworkers for errors committed on the job, and disobeying supervisor's orders are all examples of mild behavioural deviance, according to [36]. Physical violence involves things like swearing at coworkers, shaming coworkers, threatening, and attacking with injuries as a major group.

\section{B. Organizational Deviance as a Measure of Deviant Behaviour}

Non-interpersonal behaviour aimed at the organisation is referred to as organizational deviance (e.g., stealing office equipment). Theft, extortion, sabotage, and other forms of organizational deviant behaviour are aimed at organisations [2]. Deviant behaviour has been linked to workplace experience and judgments on working environments, according to research. As workers feel that management cares for their goals and beliefs, they can show their appreciation by increasing their dedication and devotion to their work. The pessimistic view of the workplace, on the other hand, leads to deviations in conduct. Employees is said to be displaying organizational deviance owing to frustration with the organization's standards and policies [37]. Production and property deviance are also examples of organizational deviance. Employees' deviant behaviour ultimately has a detrimental effect on the organization's overall efficiency [36].

\section{EMPIRICAL REVIEW}

Reference [19] investigated the effect of human resource practices on deviant workplace behaviour by workers in Pakistani banks. The cross sectional method was used to collect data from respondents, and copies of questionnaires were used. The retrieved data was analyzed using multiple regression. According to the findings, there is a connection between human resource management strategies and deviant workplace conduct.

"Human Resource Management and Deviant/Criminal Behaviour in Organizations," by [38] revealed the role that human resource departments typically perform in the control of criminal/deviant behaviour within their staff in their jobs. Many interventions have been found to help minimize the incidence of deviant conduct, including recruiting, initial assessment, and selection; preparation and development; performance management; and terminations.

Reference [39] investigated the correlation between human resource management strategies and workplace deviant behaviour, primarily interpersonal deviance. Employees would reciprocate the responsibility with good behaviours of companies with stronger human resource management policies such as placement, recruitment, career planning incentives, performance assessment, work description, and employee engagement, according to the study's hypotheses. The fact that human resource management practices had a detrimental relationship with behavioural deviance behaviour is evidence of this. Reference [18] investigated the impact of human resource management practices on interpersonal deviance at work through job satisfaction. Three hundred and seventy-two industrial workers from various occupational ranks in manufacturing firms in Malaysia's northern area were included in the analysis. Data was gathered using a questionnaire distributed to participants with the aid of the human resource department, which asked them to rate the extent with which their co-workers engaged in different forms of interpersonal deviance. The findings were evaluated using regression analysis, and it was discovered 
that human resource management strategies such as work description, internal work prospects, and employment protection had a connection to interpersonal deviance. It was discovered using regression that there is a clear connection between work satisfaction and interpersonal deviance. The aspects of career satisfaction have moderated the association between human resource management activities and interpersonal deviance.

Reference [20] also looked at the effect of human resource management practices on deviant behaviour in employees. The research used an observational analysis as well as a main source of data obtained by a questionnaire. The data was analyzed using Pearson Product Moment Correlation (PPMC), and the findings showed that there is a connection between human resource management activities and employee deviant conduct. The research also discovered that there is a connection between human resource management practices and deviant behaviour among Justice Department employees.

\section{Methodology}

This study made use of the cross-sectional survey design which is a type of the quasi-experimental design. A total population of 470 employees from six (6) manufacturing firms were covered. The [40] formula was used to arrive at a sample size of 216 employees which served as the respondents. The simple random sampling technique was used on each of the six selected companies. The predictor variable (HRMP) was operationalized in terms of compensation and employee relations as given in [9]. 5 items were used in measuring compensation (e.g., I am satisfied with the amount of pay and other benefits I receive in this organization) and 4 items were used in measuring employee relations (e.g., My relationship with my supervisor is a harmonious one). Deviance behaviour were measured using interpersonal deviance and organizational deviance as contained in [2]. 5 items were used in measuring interpersonal deviance (e.g., In my organization, Employees act rudely toward someone at work) and 5 items were used in measuring organizational deviance (e.g., Employees do take property from work without permission). Copies of questionnaires were utilized to gather data from respondents. The response to these items were measured on a 4-point likert, scales ranging from $1-4$. Where $1=$ Strongly disagree, 2 = Disagree $3=$ Agree and $4=$ Strongly agree . Spearman Rank Order Correlation Co-efficient was used in analysing the data.

\section{Result}

From a total of 216 copies of questionnaires that were distributed to respondent, $170(78.7 \%)$ copies were returned and utilized. The hypotheses test was undertaken at $95 \%$ confidence interval implying a 0.05 level of significance. The decision rule is set at a critical region of $\mathrm{p}>0.05$ for acceptance of the null hypothesis and $\mathrm{p}<0.05$ for rejection of the null hypotheses.

Hypothesis One: There is no significant relationship between Compensation and Interpersonal Deviant.

Data in Table I revealed that there is no significant relationship between Compensation and Interpersonal Deviant $(\mathrm{p}=.151$ and rho $=0.111)$ hence we find that Compensation is not associated with Interpersonal Deviant and based on the decision rule of $\mathrm{p}>0.05$ for null acceptance; we therefore uphold the null hypothesis that there is no significant relationship between Compensation and Interpersonal Deviant.

TABle I: COMPENSATION AND MEASURES OF WORKPLACE DEVIANT BEHAVIOUR Correlations

\begin{tabular}{|c|c|c|c|c|c|}
\hline & & & Compensation & $\begin{array}{c}\text { Interpersonal } \\
\text { deviant }\end{array}$ & $\begin{array}{c}\text { Organizational } \\
\text { deviant }\end{array}$ \\
\hline \multirow{9}{*}{ Spearman's rho } & \multirow{3}{*}{ Compensation } & Correlation Coefficient & 1.000 & .111 & -.324 \\
\hline & & Sig. (2-tailed) & . & .151 & .000 \\
\hline & & $\mathrm{N}$ & 170 & 170 & 170 \\
\hline & \multirow{3}{*}{ Interpersonal deviant } & Correlation Coefficient & .111 & 1.000 & .038 \\
\hline & & Sig. (2-tailed) & .151 & . & .621 \\
\hline & & $\mathrm{N}$ & 170 & 170 & 170 \\
\hline & \multirow{3}{*}{$\begin{array}{l}\text { ORGANIZATIONAL } \\
\text { DEVIANT }\end{array}$} & Correlation Coefficient & -.324 & .038 & 1.000 \\
\hline & & Sig. (2-tailed) & .000 & .621 & . \\
\hline & & $\mathrm{N}$ & 170 & 170 & 170 \\
\hline
\end{tabular}

TABLE II: EMPLOYEE RELATIONS AND MEASURES OF WORKPLACE DEVIANT BEHAVIOUR Correlations

\begin{tabular}{lllccc}
\hline & & \multicolumn{2}{c}{$\begin{array}{c}\text { Employee } \\
\text { relation }\end{array}$} & $\begin{array}{c}\text { Interpersonal } \\
\text { deviant }\end{array}$ & $\begin{array}{c}\text { Organizational } \\
\text { deviant }\end{array}$ \\
\hline & \multirow{3}{*}{ Employee relation } & Correlation Coefficient & 1.000 & $\mathbf{- . 2 0 6}$ & $\mathbf{- . 2 2 3}$ \\
& & Sig. (2-tailed) &. & $\mathbf{. 0 0 7}$ & $\mathbf{. 0 0 4}$ \\
& & $\mathrm{N}$ & 170 & 170 & 170 \\
Spearman's rho & Interpersonal deviant & Correlation Coefficient & $\mathbf{- . 2 0 6}$ & 1.000 & .038 \\
& & Sig. (2-tailed) & $\mathbf{. 0 0 7}$ &. & .621 \\
& & $\mathrm{~N}$ & 170 & 170 & 170 \\
& Organizational & Correlation Coefficient & $\mathbf{- . 2 2 3}$ & .038 & 1.000 \\
& Sig. (2-tailed) & $\mathbf{. 0 0 4}$ & .621 & 170 \\
& deviant & $\mathrm{N}$ & 170 & 170 & 170 \\
\hline
\end{tabular}




\section{Hypothesis Two: There is no significant relationship between Compensation and Organizational Deviant.}

Data in Table I revealed that there is a significant relationship between Compensation and Organizational Deviant $(\mathrm{p}=.000$ and rho $=-0.324)$. However, a negative relationship exists among the variables. This means that an increase in Compensation will lead to a decrease in Organizational Deviant vice versa. Based on the decision rule of $\mathrm{p}<0.05$ for null rejection; we therefore reject the null hypothesis and restate that there is a significant relationship between Compensation and Organizational Deviant.

Hypothesis Three: There is no significant relationship between Employee Relations and Interpersonal Deviant.

Data in Table II revealed that there is a significant relationship between Employee Relations and Interpersonal Deviant $(\mathrm{p}=.007$ and rho $=-0.206)$, however, the relationship was negative. This means that, an increase in Employee Relations will lead to a decrease in interpersonal Deviant vice versa. Based on the decision rule of $p<0.05$ for null rejection; we therefore reject the null hypothesis and restate that there is a significant relationship between Employee Relations and Interpersonal Deviant.

Hypothesis Four: There is no significant relationship between Employee Relations and Organizational Deviant.

Data in Table II revealed that there is a significant relationship between employee relations and organizational deviant ( $\mathrm{p}=.004$ and rho $=-0.223$ ), however, the variables were negatively correlated. This means that, an increase in Employee Relations will lead to a decrease in organizational deviant and vice versa. Based on the decision rule of $\mathrm{p}<0.05$ for null rejection; we therefore reject the null hypothesis and restate that there is a significant relationship between employee relations and organizational deviant.

\section{DISCUSSION OF FINDINGS}

Human resources management practices have a detrimental linear association with workplace deviant behaviour, according to the findings of this report. The following is a systematic discussion based on the aforementioned findings:

\section{Hypothesis one:}

There is no connection between compensation and interpersonal deviant behaviour. Table I shows that reward and interpersonal deviant have no substantial association ( $p$ $=.151$ and rho =0.111). As a result, the null statement is embraced and maintained. This means that the interpersonal deviant is unaffected from any rise or alteration in pay. This suggests that, regardless of compensation increases, interpersonal deviance stays the same. This contradicts the results of [38], who found that compensation tends to minimize the incidence of interpersonal deviant behaviour.

\section{Hypothesis two:}

There is no significant relationship between compensation and organizational deviant; nevertheless, table one showed a significant relationship between compensation and organizational deviant ( $\mathrm{p}=.000$ and rho $=-0.324)$. As a result, increasing compensation would reduce corporate deviant conduct. As a result, the study's second goal, which was to see whether pay had something to do with organizational deviance, was met. This observation is consistent with that of [19], who found a connection between compensation and organizational deviant.

\section{Hypothesis three:}

Employee Relations and Interpersonal Deviant have no meaningful interaction; nevertheless, Table II shows that there is a significant negative association between employee relations and interpersonal deviant ( $\mathrm{p}=.007$ and rho $=$ 0.206). Employee interactions, on the other hand, have a 0.206 association with behavioural deviant, according to the results of the Spearman correlation (r). This indicates that Employee Interactions and Interpersonal Deviant have a detrimental significant association. This means the interpersonal deviant has a moderately hostile and serious association with employee interactions. This suggests that improving employee interactions would reduce behavioural deviant behaviour and vice versa. This observation is consistent with that of [39], who found a detrimental relationship between employee interactions and behavioural deviance conduct.

\section{Hypothesis four:}

Employee relations and organizational deviant have no meaningful interaction; nevertheless, Table II shows that there is a significant negative association between employee relations and organizational deviant $(\mathrm{p}=.004$ and rho $=$ 0.223). This means that any rise or improvement in workforce relations has a detrimental impact on organizational deviant. This suggests that as staff interactions improve, corporate deviant is mildly affected. This result is consistent with [18] results, which found that employee interactions were negatively associated with organizational deviance.

\section{CONCLUSION/RECOMMENDATIONS}

Workplace deviant behaviour is described as behaviour that has the potential to disrupt the organization's ability to operate effectively. Employees that engage in deviant behaviour are more likely to be inefficient in the workplace. Based on the results, it is apparent that compensation has no significant relationship with interpersonal deviance, but compensation may have a significant relationship with organizational deviance. Employees are more inclined to engage in corporate deviant behaviour in attempt to achieve justice because they experience inequity between their commitment and the benefits they earn. As a result, human resource management techniques are essential in reducing the level of deviant behaviour in manufacturing companies. Furthermore, both behavioural and organizational deviance have a detrimental association with employee interactions. This is to say that organizations cordial interpersonal relations are able to reduce the deviant behaviour of their employees. To summarize, an efficient human resource management practice in terms of compensation and employee relations is critical in minimizing the occurrence of deviant behaviours by manufacturing workers. The following suggestions are made based on the results and conclusions:

1. Manufacturing company management can ensure that job compensation is motivating, since this would serve to minimize organizational deviance conduct. 
2. Manufacturing company management should strive for a positive employee relationship in the workplace, since this would tend to minimize the occurrence of individual deviant behaviour in the workplace.

3. Manufacturing company management can therefore guarantee that job pay is commensurate with the rise in the standard of quitting, and this would further discourage organizational deviance.

4. Manufacturing company management can improve staff relations by caring for workers' well-being and maintaining industrial cohesion, since this would tend to minimize human and organizational deviant conduct.

\section{REFERENCES}

[1] I.N. Norsilan, Z. Omar, and A. Ahmad, "Workplace deviant behavior: A review of typology of workplace deviant behaviour". Middle-East Journal of Scientific Research. Vol. 19, no. 6, pp. 34-38, 2014.

[2] R.J. Bennett, and S.L. Robinson, "Development of a measure of workplace deviance". The Journal of Applied Psychology, vol. 85, no. 3, 349-360, 2000.

[3] M. Waseem, "Deviant workplace behaviours in organizations in Pakistan". The Lahore Journal of Business, vol. 4, no. 2, 93 - 104, 2016.

[4] I.K. Tuzun, and R.A. Kalemci, "Workplace deviance and human management relations: A case study of Turkish hotel employees". Journal of Human Resources in Huspitality \& Tourism, vol. 17, no. 2 , pp. 137-153, 2017.

[5] S.L. Robbison, and R.J. Bennett, (2004). A typology of deviant workplace behaviors: A multidimensional scaling study, Academy of Management Journal, 38(2), 555-572, 2004.

[6] K. Narayanan, and S.E. Murphy, "Conceptual framework on workplace deviance behaviour: A review". Journal of Human Values, vol. 23, no. 4, pp. 1-30, 2017.

[7] K.M. Saifalislam, A. Osman, and M.K. Alqudah, "Human resource management practices: Influence of recruitment and selection, and training and development on the organizational performance of the Jordanian public university". IOSR Journal of Business and Management, vol. 16, no. 5, pp. 43 - 46, 2014.

[8] I.N. Braje, A. Aleksic, and S.R. Jelavic, "Blame it on individual or organization environment: what predicts workplace deviance more?" Social Sciences, vol. 9, no. 99, pp. 1-12, 2020.

[9] G. Dessler, "Human resource management", $11^{\text {th }}$ eleventh edition, Prentice-Hall: Englewood Cliffs, 2007.

[10] B. Myloni, A. Harzing, and H. Mirza, "Human resource management in Greece have the colours of culture faded away", International Journal of Cross Cultural Management, vol. 4, no. 2, pp. 59 - 76, 2003.

[11] J.K. Harter, F.L. Schmidt, and T.L. Hayes, "Business unit level relationship between employee satisfaction, employee engagement and business outcome: A meta-analysis", Journal of Applied Psychology, vol. 87, no. 2, pp. $268-279,2002$.

[12] H. Elrehail, A. Alzghoul, S. Alnajdawi, and H.M.H. Ibrahim, "Employee satisfaction, human resource management practices and competitive advantage: the case of Northern Cyprus", European Journal of International Management, vol. 11, no. 8, pp. 1-25, 2019.

[13] S. Pradhan, "Leadership and deviant work behavours: the role of moral agents in today's transactional world". Global Research Analysis, vol. 2, no. 6, pp. 127 - 129, 2013.

[14] M. Rafiee, R. Hoveida, and S. Rajaeipoor, "The relationship of the deviant workplace behavour with the organizational justice and staff development in the Universities of Tehran". International Journal of Human Resources Studies, vol. 5, no. 1, pp. 126 - 140, 2015.

[15] W. Brice, and D.E. Rupp, "The psychology of workplace deviant and criminal behaviour", The Journal of Criminal Law and Criminology, vol. 105 , no. 2 , pp. $533-548,2015$.

[16] A. Ahmad, and Z, Omar, "Reducing deviant behaviour through workplace spiritually and job satisfaction". Asian Social Science, vol. 10, no. 19, pp. $107-112,2014$.

[17] F. Omar, F.W. Halim, A.Z. Zainah, H. Farhadi, R. Nasir, and R. Khairudin, "Stress and job satisfaction as antecedents of workplace deviant behaviour", Journal of Administrative Sciences, vol. 6, pp. 39$71,2011$.

[18] F.M. Shamsudin, C. Subramaniam, and H. Ibrahim, Human resource practices and deviant behavour at work: an exploratory study.
International Conference on Business and Economics Research, vol. 16 , pp. $13-17,2014$.

[19] R. Saeed, M.S. Mizna, R.N. Lodhi, A.A. Gill, A. Amin, Sinra and A. Iqbal, "Impact of human resource practices on deviant workplace behaviour: A study of banking employees", Journal of Basic and Applied Scientific Research, vol. 4, no. 2, pp. 81-86, 2014.

[20] S.A. Masole, "The impact of human resource practices on employee deviant behavior case study: Employee of the department of justice". Journal of Applied Biological Science, vol. 5, no. 2, pp. 305 - 312, 2015.

[21] G.I. Umoh, and I.H. Wokocha, Production improvement function and corporate operational efficiency in the Nigerian manufacturing industry. Journal of Information Engineering and Application, vol. 3, no. 10, pp. 39-45, 2012.

[22] A.C. Klotz, and M.R. Buckley, "A historical perspective of counter productive work behavior targeting the organization", Journal of Management History, vol. 19, pp. 114 - 132, 2013.

[23] R. Bennett, and S. Marasi, Workplace deviance. In Howard S. F. encyclopedia of mental health, $2^{\text {nd }}$ edition, 4, Waltham, M. A: Academic press, 2016, pp. $382-386$.

[24] E.A. Ross, Social Control: A survey of the foundations of order, 1901.

[25] G.L. Stewart, and K.G. Brown, Human resource management: Linking strategy to practice (2nd ed.). Danvers, MA: John Wiley \& Sons, 2011.

[26] M. Thite, "Strategic global human resource management: Case study of an emerging Indian multinational". Human Resource Development International, vol. 15, 239-247, 2012.

[27] D. Marsden, "Individual employee voice: renegotiation and performance management in public services", International Journal of Human Resource Management, vol. 18, no. 7, 1263-78, 2007.

[28] E. Essien, Psychology applied at work: An introductory approach, Ibadan: Sceptre Prints Limited, 2002.

[29] O.E. Sule, S.I. Amuni, K.A. Obasan, and H.A. Banjo, "Wages and salaries as a motivational tool for enhancing organizational performance: A survey of Nigerian workplace", Euroeconomica Journal, vol. 34, no. 1, pp. 7-26, 2015.

[30] E. Amah, Human Resources Management, Port Harcourt: Tema \& T. Press, 2016.

[31] N. Krume, D. Janka, and K. Blagica, From Industrial Relations to Employment Relations with Focus on Employee Relations, 2016.

[32] D.E. Guest, and R. Peccei, "Partnership at work: mutuality and the balance of advantage", British Journal of Industrial Relations, vol. 39, no. 2 , pp. 207-36, 2008.

[33] M. Armstrong, A Handbook of Human Resource Management Practice, London: Kogan Page Limited, 2008.

[34] Y. Liu, and C. Qiu, "Unethical pro-organizational behaviour: Concept, measurement and empirical research". Journal of Human Resource and Sustainability Studies, vol. 3, pp. 150-155, 2015.

[35] M.S. Hosain, "Unethical pro-organizational behaviour: Concepts, Motives and unintended consequences", Asian-Pacific Journal of Management Research and Innovation, vol. 15, no. 4, pp. 133 - 137, 2019.

[36] V. Chirasha, and M. Mahapa, "An analysis of the causes and impact of deviant behaviour in the workplace. The case of secretaries in State universities", Journal of Emerging Trends in Economics and Management Sciences, vol. 3, no. 5, pp. 415-421, 2012.

[37] G. Mathur, and A.S. Chauhan, "Analyzing the relationship between depression, abusive supervision and organizational deviance: An SEM approach", Journal of Human Resource Management, vol. 21, no. 1, pp. 1-13, 2018.

[38] P. Benson, G.M. Hanley, and W. Scroggins, "Human resource management and deviant/criminal behaviour in organization", in Deviant and Criminal Behaviour in the Workplace, S. M. Elias, New York, NY: New York University Press, 2013, pp. 128-151.

[39] J.B. Arthur, "Do HR system characteristics affect the frequency of interpersonal deviance in organization? The role of team autonomy and internal labour market practice". Industrial Relations, vol. 50, no. 1, pp. 30-56, 2011.

[40] T. Yamane, Statistics, An introductory analysis, $2^{\text {nd }}$ edition, New York, Harper and Row, 1968. 


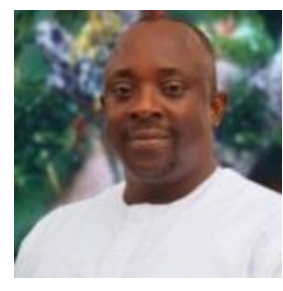

Omoankhanlen Joseph Akhigbe, Ph. D has been assessed and interviewed for the position of Associate Professor of Management \& Human Resources at the Department of Management, University of Port Harcourt, Port Harcourt Nigeria. He served as head of the Department of Management, University of Port Harcourt 2018 2020. He received his $\mathrm{PhD}$ (Business Management; April 2010); M. Sc (Business Management; September 2006) both from Ebonyi State University (EBSU), Abakaliki, Ebonyi State - Nigeria; B. Sc (Business Administration; July 2004); Diploma (Banking \& Finance; May 2000) both from Ambrose Alli University, Ekpoma Edo State -Nigeria. He has been working as a university lecturer since 2004. His teaching and research experience span across three Nigerian Public Universities [Ebonyi State University Abakaliki (2004-2005), Ambrose Alli University, Ekpoma - Edo State (2006-2011) and University of Port Harcourt - Rivers State (2012 - till date)]. Dr Akhigbe is a Member of the prestigious Academy of Management Nigeria (MTAMN) and Graduate Member of Nigerian Institute of Management (NIM). He was the best graduating student of the Faculty of Social Sciences, Ambrose Alli University Ekpoma Nigeria in 2002/2003 Academic Session with CGPA of 4.10 points on 5-point scale. He has published widely in over fifty (50) local and international journals of which many of them are in high impact factor journals.

Mutairu Momodu Adamu is a Master Student of Management in the Department of Management, University of Port Harcourt, Port Harcourt Nigeria. 